\title{
THE ANODYNE NECKLACE: A QUACK REMEDY AND ITS PROMOTION
}

\author{
by
}

\author{
FRANCIS DOHERTY *
}

Infant mortality in the eighteenth century was notoriously high, ${ }^{1}$ and much of the morbidity and mortality was directly attributed to teething, both in the vulgar mind, ${ }^{2}$ and, equally, in the medical. ${ }^{3}$

No one wanted to lose a child, even though parental affection and attachment might not be as strong in times of high infant mortality. ${ }^{4}$ There would always be a ready market for any product which somehow guaranteed protection for a child against "Feavers, Convulsions, Consumptions, Ruptures, Chincoughs, Rickets, and such attendant Distempers". 5

Throughout the century there was a remedy at hand that claimed to protect the teething infant from all the associated childish and potentially fatal conditions. There was a necklace which, when placed around the neck of the child, and left to do its quiet work, protected it.

*Francis Doherty, MA, Senior Lecturer, Dept. of English, University of Keele, Keele, Staffs. ST5 5BG.

${ }^{1}$ See, e.g., George Rosen, 'A slaughter of innocents: aspects of child health in the eighteenth-century city', Studies in eighteenth-century culture, vol. 5, American Society for Eighteenth-Century Studies, University of Wisconsin Press, 1976, pp. 293-316. For example, Rosen quotes William Cadogan's Essay upon nursing and the management of children of 1748: "But let anyone, who would be fully convinced of this matter, look over the Bills of Mortality, there he may observe, that almost half the number of those who fill up the black List, die under five Years of Age: So that Half the people that come into the World go out of it again before they become of the least Use to it, or themselves. To me, this seems to deserve serious Consideration."

${ }^{2}$ E.g., in John Thomas Smith, Nollekens and his times (first published in 1828), The World's Classics, London, 1929, p. 150: "Nollekens, when noticing nursery-maids with little children, would always make enquiries as to the cutting of the child's teeth, that I remember once his stopping to express his sense of the kindness of a mother who had made a pudding for her child's head, by saying, 'Ay, now what's your name?'."

${ }^{3}$ E.g., A full view of all the diseases incident to children ... teething, with all the various accidents which attend that critical stage of childhood, and the most effectual methods to prevent or remove them, are fully laid down by Boerhaave and Harris, as contained in this collection, London, 1742.

${ }^{4} \mathrm{~A}$ most telling observation is that made in the autobiography of Edward Gibbon: "The death of a new-born child before that of its parents may seem an unnatural, but it is strictly a probable, event: since of any given number, the greater part are extinguished before their ninth year, before they possess the faculties of mind or body." (Edward Gibbon, Memoirs of my life, ed. Georges A. Bonnard, London, Thomas Nelson, 1966, p. 28.)

${ }^{5}$ Advertisement in The British Apollo: Or, Curious Amusements for the Ingenious, Friday 8 AprilWednesday 13 April 1709 for the necklaces of "Major Choke": "Those well known Necklaces prepar'd by Major Choke, in a manner Miraculous, absolutely easeth Children in breeding and cutting their Teeth, without pain. They, preventing Feavers, Convulsions, Consumptions, Ruptures, Chincough, Rickets, and such attendant Distempers, to the Admiration of Thousands in the City of London, are still to be sold for the publick good at $5 \mathrm{~s}$. apiece, with Directions, and a Catalogue of several sufficient House-keepers, who have experienc'd them ...". Published while this article was in press was, Roy Porter, Health for sale: 


\section{The Anodyne Necklace: A quack remedy and its promotion}

Such necklaces may well have drawn on long tradition in the use of the root of the peony in the treatment of children's ailments. Gerard's popular Herbal of 1597, enlarged by Johnson in 1633, quoted Galen's observations on the use of peony roots as necklaces, ${ }^{6}$ and John Quincy's A compleat English Dispensatory carried on the traditional view of peony root necklaces into the eighteenth century. He wrote in his entry 'PAEONIAE, of Piony': "The good Women make much of Necklaces made of them to hang about Children's Necks, for Convulsions and difficult breeding of Teeth."7 There was obviously no need to go any further than an appeal to tradition if one were going to market necklaces (though it is interesting that no one who did ever appealed to the force of Galen's authority or the virtues of the peony root) but the problems with such a remedy are obvious to us, even if the wearing of protective amulets, bracelets, rings, and necklaces is as old as man. It is a bit like the sprinkling of elephant-powder around the house to protect it from marauding elephants. That is, there is a self-fulfillingness about the whole enterprise. Any parent who could afford the price of a necklace-five shillings even in $1709^{8}$ - was the kind of parent who could provide environmental conditions for the child better than the average for the time. Cleanliness, comfort, a good quality of life, rather than the insanitary, overcrowded, poorly-ventilated conditions of so many would keep some of the conditions at bay. So, the fact that a child survived, wearing the necklace, was no proof at all that the necklace did its work: but this was, of course, the claim. Equally, any parent who could read about the necklaces in advertisements or other promotional literature almost certainly belonged to a high socio-economic group.

At the start of the eighteenth century a quack is to be found promoting his own necklaces: "Major Choke", calling himself variously "one of his Majesties Chymists" or "one of King Charles Chymists" or "one of his late Majesties Chymists", or, more simply, "the great TRAVELLER". 9 But we are also warned in a contemporary pamphlet not to be taken in by his necklaces or himself: "Beware of a pretended Necklace Father'd upon one Choke, who was Nick named Major by his Fellow-Servants, he himself being an illiterate labouring Man in a Chymist's Laboratory." ${ }^{10}$ Labouring man or not, he filled his handbills impressively with the names of those who had benefited from his necklaces, the "Children of Honourable and worthy Parents, and

quackery in England, 1660-1850, Manchester University Press, 1989: see especially pp. 8, 103-4. See also Ben Zuber Swanson, 'Methods and media of dental advertising, ca. 1700-1921', M.Phil. thesis, University College London, 1987.

6 The herball or general historie of plantes. Gathered by John Gerarde of London master in chirurgerie Very much enlarged and amended by Thomas Johnson Citizen and apothecarye of London, London, 1633. Lib. 2., Chap. 380, 'Of peionie', pp. 980-84: " $\mathrm{C}$ It is found by sure and evident experience by Galen, that the fresh root tied about the necks of children, is an effectual remedie against the falling sickness; but unto those that are growne up in more yeares, the root thereof must also be ministered inwardly. D It is givne, saith Pliny, against the disease of the minde. The root of the male Peionie is preferred in this cure." ('The vertues', p. 984)

7 John Quincy, Pharmacopoeia officinalis et extemporanea; or a compleat English dispensatory, 4th ed., London, 1722, p. 82.

${ }^{8}$ That five shillings represented some two weeks' wages for a footman, 120 dishes of coffee in a coffee house, or a gallon of claret, for example.

9 E.g., British Library, London (henceforth, “BL”) catalogue number C112 f.9(87): The British Apollo, no. 148, 2-5 March 1711.

${ }^{10}$ BL 1174 b. 11 (8). 


\section{Francis Doherty}

other sufficient house keepers that have had their Children in great Extremity". Great play was naturally made with the rank of the people, always a good marketing point, and he was able to run from "A Child of the Countess of Northumberlands" and "the Children of the Earl of Exeter", through Major Generals, Baronets, Esquires, the "Suttler to the King's Regiment in Scotland Yard" to the "Glass seller next door to the Sun Tavern within Cripplegate". Additionally, one handbill names 18 outlets in London for Choke's necklaces, from "Coat-sellers" to a "Fruiterer", "Upholsterer", "Shoemaker" and other trades, as well as two booksellers. ${ }^{11}$

The handbill was kept up-to-date by adding and subtracting names from the illustrious list, but the outlets were dramatically reduced to a single one. Initially this was to be "Adam Livingstone, Fruiterer, at the South Entrance of the Royal Exchange in Cornhill", one of the long list of previous points of sale. ${ }^{12}$ But by 1711 , Livingstone had been replaced by someone with a shop in the same general location. This was a person whose name was to be associated with quack medicines and the necklace trade for many years, Mrs Garway. Initially she operated from both her shop and her home: "to be sold only by Mrs. Garway, at her shop the South Entrance of the Royal Exchange in Cornhill, and at her House at the End of Swithing's-Rents next the Old-Amsterdam Coffee-House". ${ }^{13}$ In 1709 she was operating from her shop only, and by that date Choke may well have died, as a newspaper advertisement that she had placed seems to suggest:

Those well known Necklaces prepar'd by Major Cloke [sic], in a manner Miraculous, absolutely easeth Children in breeding and cuting [sic] their Teeth, without pain. They, preventing Feavers, Convulsions, Consumptions, Ruptures, Chincoughs, Rickets, and such attendant Distempers, to the Admiration of Thousands in the City of London, are still to be sold for the publick good at 5s. apiece, with Directions, and a Catalogue of several sufficient House-keepers, who have experienc'd them, by Mrs. Garway at the South entrance of the Royal Exchange ... ${ }^{14}$

She was a seller of several quack nostrums, in addition to the necklaces, for instance, a "Most Excellent Cephalick Water, or Liquid Snuff", 15 and "Elixir Proprietatis, known by all Physicians to be the greatest Cordial, and only Medicine in the World for a long and sound Life, restoring Nature at the Point of Death, and effectually taking away the Seeds of all Diseases; it being richly prepar'd". ${ }^{16}$ She added her own touches to the promotion, deciding on the upper-class image of a coat-of-arms as a seal to the

11 BL C112 f. 9 (8).

12 BL C112 f. 9 (133).

13 BL C112 f. 9 (178).

14 The British Apollo: Or Curious Amusements for the Ingenious, 1-6 April 1709.

15 Ibid., 6-8 April 1709, carried the following advertisement: "A Most Excellent Cephalick Water, or Liquid Snuff, the same that was Prepar'd for our late most Gracious Queen, which powerfully suppresseth the Vapours in Men, or Women, it cureth these Distempers following, viz. Head-ach, Giddiness, Disiness, Convulsions, with several other Distempers. It is of Admirable Use for all Gentlemen to mix with their Powder Snuff, to Prevent the Cloging of the Brain, and all other Accidents that attend the custom of taking dry Snuff. The Bottles are sealed with three Flour-de-Luces on a Bend Sinister to prevent Counterfeits. By Mrs. Garway at the South Entrance of the Royal Exchange, Cornhill."

${ }^{16}$ BL C112 f. 9 (178). 
packaging and for the newspaper advertisements-“A Pile surmounted by a Fess between four Leopards Heads, without which they are not right". 17

For the next few years she continued to advertise and market the necklaces, while other quack remedies came and went in her shop. ${ }^{18}$ Her advertising, however, was unadventurous, and she merely repeated the formulae of the now out-of-date Choke advertisements of a decade earlier, ${ }^{19}$ without any mention of his name. She had taken over completely.

\section{THE ANODYNE NECKLACE}

But by 1717 Mrs Garway's shop was also an outlet for the necklace that was to become far more famous than that of the "great Traveller". This was the Anodyne Necklace, and this replacement was one fruit of a savage war that was going on for the domination of the necklace market. There was a battle between the necklace men and the other quacks in the teething business, in addition to the struggles between the various necklace men themselves. A four-side handbill plainly attacked the Choke necklace's list of satisfied customers, for example:

I shall here End this tedious Catalogue with this Satisfaction, that it is not ridiculously stuft up with the Names of Persons, some of whom have above 30 or 40 Years since been deceased, and the rest no where to be found, (a method made use of by some, to promote amongst the Ignorant the Sale of those insignificant Trifles, known by the name of Necklaces) but those I enumerate here, are not only living, but may easily be found out, or heard of, to justifie that what is related of the admirable Effects of this Medicine, is really matter of Truth. ${ }^{20}$

But necklaces were where the money was, and competition was fierce. More sophisticated methods of promotion were being introduced, and the days of relying on a simple, impressive list of customers were numbered. Free "books" were being offered for collection "to any that will but ask for" them, as the newspaper advertisements said, though the amount of information that was not simply a disguised, fuller advertisement varied widely. There was to be a long history of give-away booklets,

${ }^{17}$ BL C112 f. 9 (177). The British Apollo throughout March 1711 carried the advertisement, which said that the nostrum was "Sealed with this Coat of Arms, if otherwise they are Countrefeits [sic]". BL C112 f. 9 (178) has: "The said Mrs. Garway is the only Person in or about London so authoriz'd to sell the same by the original Author; and that you may not be deceiv'd, all that have not the Coat of Arms here printed, are counterfeit and false."

${ }^{18}$ E.g. The Daily Courant, 6 Jan. 1717 carried an advertisement for "Riders' Lozenges, famous for the Cure of the distemper, vulgarly called the Heart-burning: sold, Wholesale and Retail, by Mrs. Garway at the Royal-Exchange, London ....".

${ }^{19}$ The Daily Courant, 6 Jan. 1717, and The Daily Journal, 12 Jan. 1717: "The Famous Necklaces, for easing young Children in Breeding and Cutting their Teeth without Pain, thereby preventing (by God's Assistance) Fevers, Convulsions, Consumptions, Ruptures, Chin-Coughs, Rickets, and such attendant Distempers, to the Admiration of Thousands of Persons in this City of London, and Counties adjacent, who have experienced the same to the great Comfort and entire Satisfaction of their Parents, besides the decrease in the Bills of Mortality. These Rare Necklaces are sold, for the Publick Good, 5s. each, with a Catalogue of the Names of the many Children of Honourable and Worthy Parents, and other sufficient Housekeepers, who, by wearing these Necklaces, have recovered, when there was but little Hopes of Life. Sold only by Mrs. Garraway, at the Royal Exchange in Cornhill, London."

${ }^{20}$ BL C112 f. 9 (162). 
many of which purport to be of the all-you-need-to-know kind. ${ }^{21}$ Into the necklace trade came such a "free book", advertised, as in September 1715, as 'A Philosophical ESSAY upon Actions on distant SUBJECTS', looking at such current physical ideas as Sympathy and Antipathy. ${ }^{22}$ The title-page was unwieldy, cluttered, and aimed at catching the ignorant but general reader, not the scholar or the learned. But, as the advertisements developed, there was a shift away from such lumbering title-pages to that more naturally snob-oriented plug for a necklace which came with the addition of a weighty name, that of "Dr. Chamberlen". The particular Chamberlen here was Dr Paul Chamberlen, really a quack, but someone who carried the name of perhaps the most celebrated family of obstetricians in the seventeenth and early eighteenth centuries, whose invention of a short midwifery forceps had made their name and fortune. ${ }^{23}$ The Dictionary of National Biography credits Paul Chamberlen with the invention of the Anodyne Necklace, and of promoting it by dedicating "with consummate impudence" his 'Philosophical Essay' to "Dr Chamberlen and the Royal Society".

Whether he invented the necklace or not, he was certainly greatly instrumental in its promotion and its continued success, down into the next century. He died on 3 December 1717, after very few years' association with the necklace, and it was rather his nephew, Dr Hugh Chamberlen, who was very much in the public eye until his death in 1728. The public could easily be bamboozled into thinking that a Chamberlen was a Chamberlen, and that one of the famous family doctors was as good as any of them. How were they to distinguish the fashionable doctor with whom Swift dined, the man who attended Atterbury in the Tower, from his more disreputable uncle? And the name of Dr Hugh Chamberlen the elder, who had been associated with William Dockwra with the founding of the London post in 1680, was perhaps as famous. ${ }^{24}$

Several early instances of the 'Essay' survive, with substantial differences between them. ${ }^{25}$ A simple dedication to the Royal Society became one to "Dr. Chamberlen,

${ }^{21}$ E.g., a 16-page pamphlet of 1719: 'An Account of the Vertues, Use, Dose, and wonderful manner of Operation of the Pilulae Polychrestae. Which Speedily and Safely extirpate those Opprobria's of Physicians, the Gout, Madness and Melancholy of all Sorts, Stone and Gravel in the Kidneys \&c. herein specified.' These pills were only to be obtained from "Mr. Winstone's at the Black Boy and Comb, near Fleet Bridge in Fleet-street, at One Guinea per Bottle ... Where this Book is given away gratis, to any one that will ask for it." Another example is the puff for "Gowland's Vegetable Lotion", which was "A Parlour Companion (Gratis) To Prevent Disputes and Settle Differences in PRIVATE famiLies, and To Guard against Informations. / Also A Description of the Means for Rendering us Pleasant to Ourselves and Agreeable to others' [undated].

22 The Flying-Post: Or, The Post-Master, 27-29 Sept. 1715; The Weekly Journal, or British Gazeteer, 17 Dec. 1715; The Post-Man, 20-22 Aug. 1719.

23 J. H. Aveling, The Chamberlens and the midwifery forceps, London, 1882.

${ }^{24}$ See, e.g., R. M. Willcocks, England's postal history to 1840, London, The Author, 1975, p. 27; and T. Todd, William Dockwra and the rest of the undertakers, Edinburgh, Cousland, 1952.

25 'A short Philosophical EsSA Y Upon Action on Distant Subjects. Wherein are clearly explicated according to the Principles of the new Philosophy, and Sir Isaac Newton's Laws of Motion, all those Actions commonly attributed to Sympathy and Antipathy: As, The Celebrated Supplemental Nose of Taliocotius, mentioned in Hudibras: How it happened to fall off from the Gentleman's Face at Brussels, at that very instant of time when the Porter that own'd It died 500 Miles off at Bologna? How Mother's mark their Infants? With a Receipt to prevent Hare-Lips. Why when one Person Yawns, others do the same? Whence comes the Aversion in many Persons to a Cat, Cheese, and several other things? Why Dogs bark at 
and the Royal Society", with an address on the title-page "To the Worthy Dr. Paul Chamberlen":

\begin{abstract}
Honoured Sir. You having been pleased on the 26th of Nov. 1715. to order me to let the World know expressly from YOU, and in YOUR NAME, that You Absolutely Approve of, and Advise the Wearing of the hereafter mention'd NECKLACE, To all Children for the Easy Breeding, and Cutting of their Teeth: To all Women in Labour: And to all Persons who have any Ailment in any part belonging to their Head: declaring to me at the same time that You heartily wished that all such would wear it, You being thoroly convinced of its Wonderful and Surprizing Anodyne Virtues, from a long experience which You was pleased to own to me that You had had of it, Acknowledging to me that You Your self had used it for many Years, and always with success, for these new mention'd ends: I most willingly lay hold of this occasion to inform the World of the great value and esteem You are pleased to have for it, And which still appears the more by the large Approbation which you was pleased afterwards to give of it, at your House on the 13 of Sept. 1716. incerted above in the begining of the foregoing Scheme.
\end{abstract}

In addition the outlet changes, from "the Milliner's Shop, right against the three Tuns (which is next to the Grainge-Inn) in Cary-street, facing Lincolns-Inn Fields Play-house gate, (which is but a little step up from Fleetstreet, and Temple-Bar)" to "ONLY of the Gentlewoman up ONE pair of Stairs, At the Sign of the Sugar Loaf a Confectioners Shop over against Old Round Court, near the New Exchange in the Strand. And at no other Place."

But Dr Chamberlen is reported to have given his permission to promote the

Beggars? Why (according to the New Philosophy,) 'tis said that nine Taylors make but one Man? Why Whistling makes Horses stale? With an Explication of the Load-stone, Amber, Jet, Glass, and other Electrick Bodies: Sympathetick Powder, Amulets, Cramp-rings, Blood-stones, Wearing Gold for the King's Evil, with great numbers of other such common and usual Phaenomena's. From whence it plainly appears how the wearing of a certain Anodyne / NECKLACE/makes the Breeding of Childrens Teeth wonderful easy, and even in a Night's time to Cut, without a Fever, or Pain out of the Gums; besides other its wonderful and admirable Effects on Women in Labour, and Distempers of the Head: as Tooth-achs, Head-achs, Red, Sore, and Weak Eyes, Vapours, Hardness of Hearing, Hoarseness, Sore Throats, Cramps, Fits, \&c. / Felix qui potuit rerum cognoscere causas. Virg. / This EssAY is given Gratis, to any one that will but ask for it at the Milliner's Shop, right against the three Tuns (which is next to the Grainge-Inn) in Cary-street, facing Lincoln's Inn Fields Play-house Gate, (which is but a little step up from Fleet-street and Temple-Bar. / Entered in the Hall-Book. / London, Printed in the Year 1715. [Wellcome Institute Library W 82 198]

A Philosophical Essay Upon Actions on Distant Subjects... 1715/Dedicated to the ROYAL sOCIETY. / The Third Edition. / Entered in the HALL-BOOK. / This Book is GIVEN GRATIS to ANY Person that will but ask for it, (up One Pair of Stairs) at the Sign of the Sugar-Loaf a Confectioner's Shop, against Old Round Court near the New Exchange in the / Strand.-Note, there is a Person ALways ready up One Pair of Stairs, TO GIVE these books away. [BL 1405 c. 25 (1)]

A Philosophical essay upon the Celebrated NeCkLace Recommended to the World by $\mathrm{Dr}$. Chamberlen for Children's TEETH ... / To which is added An Account of a late Discovery of a New Method of WRITING, by which Any one may Write more in a few Minutes, then otherwise they can in a whole Day. And by consequence full As Fast, As Any One can Speak. / Dedicated to Dr. Chamberlen, and the Royal Society ... [1715; Harvard University Library]

A Philosophical Essay...1717/Dedicated to Dr. Chamberlen, and the Royal SOCIETY./ LONDON: . . . 1717

Advertisements were often in the papers, e.g., The Flying-Post: Or, The Post-Master, 27-29 Sept. 1715; The Weekly Journal, or British Gazeteer, 17 Dec. 1715; The Post-Man, 20-22 Aug. 1719. 


\title{
Francis Doherty
}

necklace in as wide a way as could be conceived, and a conversation with him, reputedly on 19 November 1715 , is quoted:

\begin{abstract}
I desire (said he to me) that you will let the World know from ME, And in MY Name, that I expressly advise the Wearing of this Necklace to all Women in Labour: To all Children for their Teeth: And to all Persons that have any Ailment in any part belonging to their Head, and therefore I wish that all such Persons wou'd wear it. For (said he) I my self for many Years have used of the very same Matter of which this Necklace is made, for the very same ends, and always with success. Therefore if I MY SELF were present, I wou'd be the first Person that should put it about their Necks: For of all the things that I know in the whole World, there is nothing that can come near this Necklace for these Ends.
\end{abstract}

And, true to his professed belief in the universal efficacy of the necklaces, the "doctor" not only

almost daily send[s] great Numbers of Persons of his acquaintance to buy it, and also frequently sends for it HIMSELF for the use of his own Patients, having of late sent for a prodigious number: but also constantly, himself Wears one of these Necklaces on each Leg by way of Garters for the Cramp, which for many Years before he wore them, he was sorely afflicted with ... 26

The essay was well-publicized, and announcements were carried by The FlyingPost: Or, The Post-Master on 27-29 September 1715, and in The Weekly Journal, or British Gazeteer on 17 December 1715; and it was still being advertised four years later in The Post-Man on 20-22 August 1719. But during those four years many reorganizations, mergers, and takeovers had occurred within the area of influence of the Anodyne Necklace.

\section{THE ANODYNE NECKLACE BRANCHES OUT}

The 'Essay', like so much of the material associated with quackery, also acted as a vehicle for several other quack remedies. Initially they were the "Famous Purging Sugar-Plums", 27 the "Rheum Plaister", the "Ague Plaister", "Saffron Drops", and "Daffy's Elixir Salutis". Later, these were reduced to two, with long encomiums on

${ }^{26}$ Harvard University Library copy of 1715 , p. 41.

${ }^{27}$ Purging Sugar Plums were advertised in The Female Tatler, no. 40, 5-7 Oct. 1709 until December 1709, being sold by Mr Spooner at the Golden Half Moon in Lemon Street, Goodmans Fields near "White Chappell", as "Purging Sugar Plums for Children, and others of Nice Pallates, nothing differing in Taste, Colour, \&c. from Sugar Plumbs at the Confectioners, having been experienced by Thousands to sweeten and purifie the Blood to Admiration, kill Worms, cure Green Sickness in Maids, pale Looks in Children, Rickets, Stomach Pains, King's Evil, Scurvies, Rheumatisms, Dropsies, Scabs, Itches, Tetters, \&c., good in all Cases where Purging is necessary, doing all that is possible to be done by a purging Medicine; being the cheapest, safest, and pleasantest Medicine in the World, fit for Persons of all Ranks, Ages and Sexes. Price 1s. the Box." There was an attack on the Purging Sugar Plums, incidentally, in a notorious onslaught on Ward's Pill and Drop in The Grub-Street Journal on 28 November 1734, and a response on 12 December 1734. The imputation was that the nostrums was really antimonial, "a white sparkling powder, called Algarott; one grain of which is so rugged and harsh, working upwards and downwards, with so much pain, and such uncertainty with all, that it is seldom or never prescribed". This was vigorously denied by "The AUTHOR of the Purging Sugar Plums", who wrote that his medicine was ready to stand the test of examination by any physicians, as they had nothing of the noxious Mercurius Vitae in them. Later, "Robert's Worm Sugar Plums" were among the items scheduled in the Act for granting Stamp Duties on Medicines of 28 July 1812, and they appear with 10 other medicaments for worms. They had a long life. 
each, the "Saffron Drops" and the "Purging Sugar-Plums". But the final item that was included in the campaign was "An Easy Method to write as fast as speak, as much in one Hour, as usually in a whole Day', in 1715. In the later essay, this new promotion was to be given away to anyone who "Buys either One of the above-mention'd Necklaces: Or a Bottle of the Saffron Drops: Or a Dozen of these Sugar Plums" in English or French. Now "any Person may WRITE AS FAST AS SPEAK. Write as much in a few Minutes as usually in a whole Day ...". What this represents is the amalgamation of the quack medicines with the relatively respectable and well-documented shorthand method of Francis Tanner. ${ }^{28}$ Although he had been publishing his Shorthand since $1712^{29}$ and wrote a booklet on keeping canaries, ${ }^{30}$ through his association with the Anodyne Necklace, Tanner became a notorious figure. Both his booklets were to be obtained from a Mr Bradshaw who was to be associated with the Anodyne Necklace in various ways, eventually coming to own the whole enterprise. But at this juncture he was promoting his own particular line in quack medicines by tacking on several pages of advertisements and four sides of "Some few Certificates of Cures" for them, after the eight sides of the shorthand method. Bradshaw was vigorously promoting the Purging Sugar Plums, both for individuals and, more pressingly, for the trade to take up. He obviously wanted as many outlets as he could persuade to take his Purging Sugar Plums, his Saffron Drops, and his Rheum and Ague Plaisters, and he was a great believer in the use of the Penny Post.

And if any Shopkeeper or other Person who by reading of this Advertisement, may have a mind to any of these things, (altho' they may live some Miles off,) will but send a Penny-Post Letter to Mr. Bradshaw above-mentioned, they need put themselves to no more trouble: for they shall as soon as ever the Letter is received, have whatever they write for (altho' it be but 2 or 3 Sugar Plums) brought to them, without paying any thing at all to the Messenger for bringing them: and also their Penny Postage shall be repaid them again...

Incidentally, the bitter complaints that such Sugar Plums were really poisonous

\footnotetext{
${ }^{28}$ E. H. Butler, The story of British shorthand, London, Pitman \& Sons, 1951, pp. 62-5.

${ }^{29}$ Reference is made to a 1712 edition of Tanner's Shorthand (p. 36: "Several of the Characters may signifie whole words") in the $O E D$, s.v. 'Character': 3.

${ }^{30} \mathrm{~A}$ copy of the Shorthand in the BL (7286.p.11) is bound continuously with a 64-page pamphlet devoted to the canary and its management: 'A short Discourse of the Canary Bird. Treating of the Nature, Origin, and different Sorts of that Bird. Together with full Directions how to know and order them for Breeding or Singing only: To bring them up by Hand, and make them Tame and Familiar: To teach them any Tune or Song: To cure them of whatever Illness they are subject to: Together with whatever else can be desired to be said of that Bird. To which is added A Word or two of the Linnet, Lark, Robin, Goldfinch, and other Singing Birds. With Instructions how to Shoot Snipes, Fieldfares, Larks, and other small Game, Sitting or Flying: And raise Canary Seed of ones own. By F. T./_Inest sua gratia Parvis. Virg. / LoNDon / Printed, and Sold (by the Author's appointment) by Mr. Bradshaw, next Door to the King's-Head in Crown-Street; between Denmark-Street and Sohoe-Square near St. Giles's Church in the Fields. 1714. Price 1s.' Both pamphlets are by "F.T.", and there are two corrections in ink to the canary pamphlet, presumably for a projected second edition. "Anodyne Necklace" continued to cash in on canaries, and in 1742 the firm published a "new" booklet (owing a great deal to another book, $A$ new treatise on canary birds [etc.], a translation of a work by the French writer, Hervieux). This later Anodyne venture was $A$ new way of breeding canary birds ..., printed by "J. Hughs, in Lincoln's-Inn-Fields", to be sold at $1 s .6 d$. at the Sign of the Anodyne Necklace and at Mr Bradshaw's. It was well adorned with prints, and carried advertisements for their medicines, as usual. It seems to have been the only pamphlet for which a charge was made.
} 
compounds, either mercurial, antimonial, or arsenical, ${ }^{31}$ were vigorously combatted by Bradshaw's advertising, both in this treatise and in the press. ${ }^{32}$ Purging Sugar Plums had a long innings, and any opportunity to promote them was taken and exploited. In 1728, for instance, The Weekly Journal: Or, British Gazeteer carried a long advertisement with a logo of a man in a nightcap seated in front of a roaring fire which was entitled AGUE, and this was a commendation of "The Famous little Purging Plums" as a "now as well known present Cure, that when these Distempers were lately so very common and fatal throughout the Kingdom, they cured those immediately who took them, when sometimes Two at a Time lay Dead in Families who did not take them". As before, these were available "Wholesale and Retale" at "12d a Dozen: Or eight Shillings a Gross, with Plenty of Directions along with them, to any Shopkeepers to sell again, and a neat printed Sheet to hang out if they please".

Very much later, in 1752, there was a hint that someone connected with the Anodyne Necklace's early promotion was a "knavish and designing priest". ${ }^{33}$ This is likely to have been Tanner, though it is not entirely certain. But priest or not, the shorthand booklet was a successful addition to the promotional armoury of the Anodyne Necklace, and it continued to be advertised and given away at least until $1723 .{ }^{34}$

The amalgamation of Bradshaw's flair for wholesale promotion of nostrums with someone who could write copy, like Tanner-witness the short hand monograph and the Canary Bird treatise-together with the name of Dr Paul Chamberlen, and with fashionable outlets like the Royal Exchange, guaranteed a commercially powerful company. What it needed was a way of constantly keeping the products before the public eye. They found several.

The first was to keep up the newspaper campaigns, and, with this in mind, the devising of distinctive and instantly-recognizable logos seems to have been crucial. The coat-of-arms or seal were popular devices, and these were used by several quacks. ${ }^{35}$ But

\footnotetext{
${ }^{31}$ See note 27 , above.

32 The ingredients were claimed to be totally safe, having no mercury in them at all, but only sugar and cream of tartar: "Their whole Composition is very Simple, consisting only of two Ingredients and no more: to wit Double refin'd Sugar, and Cream of Tartar: But it is a Cream of Tartar particularly prepared for this use, stronger then the Common Cream of Tartar at the Shops; being made by a particular Art and Secret as effectual in 4, or 5 Grains, as common Cream of Tartar is in half an Ounce. And in this one thing alone lies the SECRET of these Plums ...".

${ }^{33}$ BL Tracts 298, 'The Modern QuACKS DETECTED' (1752) has a sustained attack on the Anodyne Necklace (pp. 28-37), in the course of which Tanner is contrasted with Sir Kenelm Digby, whose notorious "Wound Salve" had harmed many: "Sir Kenelm, a most renowned Personage, a very great Naturalist, but no Physician; nor has his Sympathetic Cure of Wounds any ways vacated or superceded the Practice of Surgery, (but I know where it has forty Times made Work for that Profession) any more than this ridiculous Bead-roll is like to that of Physick; they having both of them been sufficiently proved fallacious and idle Dreams; the one however of an honest and well-meaning Nobleman, the other, as was creditably reported, of a knavish and designing Priest."

34 The Folger Library has a copy which is ascribed to 1723 . It is certainly to be dated after 1722 , when the "Gout Stone" was first advertised, for it carries an advertisement for a 'Treatise' on that product; and before 1726 when the base of the operation moved from "just by the Rose Tavern without Temple-Bar" to Devereux Court. It could have been printed at any time between those dates, though the "Introduction of a New Method of Writing a great deal in a Little Time" was announced as ready to give away in the near future both on 17 November and 1 December 1722.

${ }^{35}$ It was impossible to open a newspaper without seals, emblems, and woodcuts prefixing almost every advertisement. Turner noted wittily that "shipping pages were strewn with more ships than ever sailed in
} 


\section{The Anodyne Necklace: A quack remedy and its promotion}

these were tame enough, and what became the ubiquitous symbol of the Anodyne Necklace products was the necklace itself suspended on the page between two flying angels together with a seal with an enclosed necklace surmounted by a child's head and ANODYNE and NECKLACE running round the seal. You could hardly look at the advertisement pages of any newpaper without a version of these logos catching your eye. It was extremely successful, to judge by its longevity. The bulk of the company was also increased by the acquisition of its own printer; at least, every pamphlet and "treatise" to be issued by the Anodyne Necklace firm until at least 1730 was printed by "H. Parker".

There are four non-quack items which are recorded as having been printed by " $\mathrm{H}$. Parker" before his engagement with the firm around 1714. These are all successive editions of a series of poems, Pastorals. After the simple manner of Theocritus. ${ }^{36}$ But these are rare items in a career which, after his joining "Anodyne Necklace", seems exclusively to have been in the service of the Anodyne Necklace and all its various publications.

We know that he was Henry Parker, that he was out of his apprenticeship in 1711, and that he printed the Tanner shorthand books from 1712 onwards. He was probably the son of the more famous George Parker, who was known as a publisher of almanacks and as being fiercely anti-Whig. ${ }^{37}$ George Parker had published his own medicines, and no doubt there was a connection in the quack confraternity that allowed the son fairly easy access to the printing of quack materials. ${ }^{38}$ In addition, Henry Parker printed one of his father's ephemerides, that for the year 1712-though the almanack continued its existence under various printers from 1708 to 1781 . It could be that his father was helping his son get started in the business in that year. However, we do find Henry Parker selling one of his father's nostrums, the "Coelestial Anodyne Tincture: Or, the Great Pain-Easing Medicine"39 in 1731: "It is sold only by Mr. PARKER, Printer, at his House in Salisbury-Court, or by such persons as he shall depute, viz. at Mr. Parker's, a Printer, in Bull Head Court, Jewin-Street . ..”. But with the family interests Parker also brought that of publishing almanacks, and the Anodyne

\footnotetext{
the Armada" in his observations on the "cuts and figures" which Addison had commented on in his essay on advertising in The Tatler for 14 September 1710. D. Turner, The modern quacks, London, 1718, p.27.

${ }^{36}$ D. F. Foxon, English verse 1701-1750. A catalogue of separately printed poems with notes on contemporary collected editions, Cambridge University Press, 1975, pp. 1172-5.

${ }^{37}$ Bernard Capp's Astrology and the popular press: English almanacs 1500-1800, London and Boston, Faber, Faber, 1979, devotes several pages to George Parker. He lived from 1654 to 1743, was both an astrologer and physician, making and selling his own medicines, and a High Tory propagandist who attacked the Stationers' Company for its monopoly of printing almanacks. He was first established as a cutler, and later in his career set up as a printer.

${ }^{38}$ We find Parker printing in 1711 a list of quack remedies obtainable from "Mr Lewis's Bookseller, in Russel-street. COVEnT GARDEN." In 1712, the Tanner Shorthand book was "printed by H. Parker, for W. Lewis", and the Tanner connection links Parker with the Anodyne business, which was about to get into its stride. But in 1711, Parker was working from his father's address in "Salisbury-Court, Fleet-Street", and still not launched on his own.

${ }^{39}$ The Grub-Street Journal, 11 February 1731: "It is sold only by Mr. PARKER, Printer, at his House in Salisbury-Court, or by such persons as he shall depute, viz. at Mr. Parker's, a Printer, in Bull Head Court, Jewin-street ...".
} 
Necklace firm was to produce several examples through the 1720 s and $1730 \mathrm{~s} .{ }^{40}$ More immediately, now that it was a group of people with differing kinds of expertise, it went sailing ahead.

The first thing to do was to cope with Mrs Garway. She had a name that was well-known to Londoners from the famous coffee-house with the family name, ${ }^{41}$ and she had a thriving outlet for Choke's necklaces, and so she was brought into the enterprise. This was not without some initial difficulty, as she obviously had a stock of the older necklaces, and she was going to off-load them as she could. Hence we find occasional announcements to beware that you get the right kind of necklaces from her, at a slightly later date. But the year 1717 saw first her rivalry for the necklace trade, then her adoption. We find her, for instance, publishing what is substantially a Choke advertisement on 6 January in The Daily Courant, together with her own "Rider's Lozenges famous for Cure of the Distemper, vulgarly called the Heartburning", which she sold wholesale and retail. On 26 January The Weekly Journal, or British Gazeteer was advertising Anodyne Necklaces, "Sold ONLY up one Pair of Stairs at the Sugar-Loaf, a Confectioner's Shop over against Old Round Court near the New Exchange in the Strand, and not at Mrs. Garway's at the Royal Exchange Gate, or any where else." But on 16 February that newspaper carried an announcement from "Paul Chamberlen M.D.", dated 5 February, denouncing a necklace "published in Cornhill" which claimed to be recommended by him. He asserted that the only authorized outlets were "The Sugar Loaf against Old Round Court in the Strand", "Mr Coopers by Hungerford Market", and "Mrs Garways's at the Royal-Exchange Gate". So, by February she was part of the team. Yet by the end of the year she was still being warned against: "But those Persons who go to Mrs. Garways for it, are desired to take Care, least they have another Necklace, Sold them instead of this...".

Tanner and Mrs Garway between them seem to have brought into the enterprise another money-spinner, a treatise which was to run, in a variety of forms and guises,

\footnotetext{
${ }^{40}$ The New Almanack of 1728 (?: BL); The Family Almanack of 1732, advertised in Read's Weekly Journal, or, British Gazeteer, 16 Dec. 1732-24 Feb. 1733, and in The Country Journal: or, The Craftsman, 6 Jan. 1732/3; A Supplement to All Common Almanacks, advertised in Read's Weekly Journal, 26 Feb. 1732-7 Oct. 1732, in The Daily Journal, 6 July-28 Sept. 1732, and in The Country Journal, 15 Feb. 1731-21 April 1732, and Applebee's Original Weekly-Journal, 27 May 1732; Hanover Journal, advertised in The Country Journal, 27 Nov. 1736-14 May 1737: A New Almanack for 1734, advertised in The Country Journal, 12 Jan. 1733/4-18 May 1734; Rich Robin's Almanack for 1734, advertised in The Country Journal, 10 Feb. 1733/4, and in The Country Journal, 26 May 1739-7 July 1739; and the Non Con Almanack, advertised in The Country Journal, 10 Feb. 1738/9-12 May 1739.

${ }^{41}$ Bryant Lillywhite, London coffee houses: a reference book of coffee houses of the seventeenth, eighteenth and nineteenth centuries, London, George Allen and Unwin, 1963, traces the history of the famous Garraway's Coffee House (variously "Garroway, Garryway, Garway"). This dated from before the Great Fire of London and was a noted place for auctions as well as tea and coffee sales. A Mrs Alice Garway is mentioned as having rented two rooms in Sweetings Rents in 1711 to the Sun Insurance Office. She might not have been directly connected with Thomas and Elizabeth Garraway (Garway) who ran the coffee-house, though she lived in the same area as they did, and shared the same name: however, several members of the family seemed to live near the Royal Exchange Gate. An advertisement in The Observator (vol. 2, no. 43, 1-14 Sept. 1703) for "The Honourable $R$. Boyl's most Excellent Lozenges" listed, among several outlets, that of "Mr. Garraway, at the Royal-Exchange-Gate"; three years later, the same newspaper carried an advertisment for "the Venetian Wash", and it was sold, among other places, at "Mr. Garraway's, Fruit-shop, at the Royal-Exchange".
} 
for many years in the market-place. This was the Practical treatise, purporting to explain the symptoms and cure of the venereal disease, which had been on the market since 1713. It was savagely attacked in 1719 by Joseph Cam in his own treatise, $A$ short account of the veneral disease, ${ }^{42}$ and his onslaught included several pages exposing the writer's medical ignorance, and attacking the ways in which on one occasion a medicine will be "the famous Elixir" for venereal disease, and on the next an "individual Tincture for the gout", though it was the same medicine. He advised Tanner, on the other hand, to reprint his treatise on canary birds "because its Use is extensive". But, more substantially, he attacked the advertising gimmick of publishing testimonials to the medicine from those who claim to be cured by it. These "Vouchers", he wrote, come from those whose poverty is obvious, and, when the patient is told that his guinea will be refunded and the cost of the advertisement reimbursed if a patient is willing to testify and if the medicine's cost is a guinea (which it is), then the list of "Vouchers" is as likely to be a list of dissatisfied customers getting their money back, though having to lie for it.

Tanner also provided an example, according to Cam, of the kind of extravagant claims made for a quack medicine that was being promoted:

In the first place, too much is proved by these Advertisers; for by them, it must be the Dew of Heaven! and this Gentleman has been stamp'd on purpose by the Almighty Power, to find out a Secret in a Profession he is currently Ignorant of; (as a Reward, think we, for having dropt his Priestly Function?)

But, speaking as a medical man, Cam poured scorn on the claims being made by the Anodyne Necklace firm:

As for a Specifik, I must acquaint my Reader ... that it is Physically impossible, that five or six Grains of any Medicine can produce those wonderful Alterations in a Blood and Juices so tainted; and therefore this is a ridiculous, and an absolute Chouse, to delude poor Unfortunate People, and at once to empty their Bodies and their Purses.

Finally, he produced cases where the "Scheme-Maker's Specifick Elixir ..." with his "Specifick Electuary" had been bought and tried with disastrous results, consequences which were due partly to the ingredients being quite common and without specific indications for venereal infections, or which would be specifically contra-indicated.

The other Grand Specifick which he has made such a Noise about also, and to so little Purpose, (unless to chouse People out of their Money and Health) is nothing but some of the common Purgatives; such as Rosin of Jalap, Coloquintida, and Scammony, together with Mer.Dul. made up with Balsam of Capivi; and the Danger of giving Balsam Capivi in the beginning of the Cure of Claps, thousands in this City, have experienc'd to their Ruin.

\footnotetext{
42 Advertised throughout the year, e.g., in The Post-Boy. Cam was to go on to write his own work, $A$ practical treatise: or, second thoughts on the consequences of the venereal disease, still being published in 1740. [BL 1175 1. 11]. A copy of $A$ rational and useful account of the venereal disease ... The eighth edition, corrected, with additions [?1740] exists at BL $1175 \mathrm{k} .7$ (7).
} 
Of course, anyone who had tried unsuccessfully the "Scheme-maker's" medicines would be cured by "my Elect. Mirab. my Spirit. Antidysuricus, and Balsamick Pills".

Apart from attacks like these, there usually was another side of the enterprise that had to be monitored constantly, the plagiarists and forgers who were seeking redress from the Anodyne company, whom they, in turn sought to stamp on. So, when we turn to the 'Practical Scheme' we find an advertising and pamphlet war going on. 'A PRACTICAL AND PHILOSOPHICAL SCHEME' of no date or place of publication (though likely to be around 1717), ${ }^{43}$ promises a refund of the purchase price of a guinea if a patient bought the advertised medicine and yet showed no improvement in 21 days. It singles out as useless a single nostrum, that "Specifick, Sold at Mr. Cooper's and Mrs. Garaway's", and it contrasts the many who have been unable to find help from this or "the most eminent Physicians, Hospitals, Colleges, Surgeons" with those unfortunates who did at last find "a perfect Cure by this Specifick", and a few examples are singled out for the reader. A certain M. Vaughan was quoted:

I M. Vaughan, Housekeeper for thirty Years past, in Mercer's-Street, over against the Swan Brewhouse, in Long-Acre, was so injur'd (by an infected Husband four Years ago) with the Secret Disease, when with Child,...

I apply'd my self soon after the Injury receiv'd, to the most eminent Physicians, Dr. Ratecliffe, Clarke, and every one agreed a Salivation wou'd Cure me; whereas I've since been nine Times salivated, twice fomented, fourteen Weeks in St. Thomas's Hospital, made use of a Specifick sold at Mr. Cooper's in the Strand, and at Mrs. Garway's at the Royal Exchange, and many famous Surgeons, and all to no Purpose; every one fail'd, my Hopes defeated, and left by all (in such a deplorable Condition) as Incurable. But since November last, several Advertisements being Publish'd of astonishing Cures by a particular Specifick, wrought on Persons given over by all, with their Names and Places of Abode....

This pamphlet was, in its turn, attacked in the press by the announcement of the publication and free distribution of 'A Plain and practical Discovery of the Nature and Cause of the Secret Disease ... To which is appended, The Grant Impostor discover'd; being Remarks upon the Practical and Philosophical Scheme of the Secret Disease... ${ }^{44}$ This prompted a riposte, which both alleged plagiarism by the manufacturers of "The Royal Specifick" and issued a defence of the writer's own medical expertise together with a condemnation of what was seen as a campaign of malicious disinformation being carried out against the author of the true 'Practical and Philosophical Scheme'.

\footnotetext{
${ }^{43}$ It has a seal affixed, which agrees with that attached to another "treatise", dated 1718: 'Filum Ariadneum: OR the WAY to get out of THE LABYRINTH of VENUS ... London: Printed in the Year, M. DCC. XVIII'.

44 The Weekly Journal, or British Gazeteer, 19 and 28 Dec. 1717: "Just published, and given away Gratis to to [sic] any One that will but ask for it, at Mr. Lovell's a Toy-Shop at the Sign of the Pattern, (over-against Great Suffolk-street-end near the Hay-Market, by Pall-Mall, and at Mr. Jeremiah Pain's, a Toy-Shop at the Bunch of Grapes in Pope's-Head-Alley, over-against the Royal-Exchange, Cornhill) a Plain and practical Discovery of the Nature and Cause of the Secret Disease, with a short, far more private Easy, and compendious Method of its Cure, than any hitherto extant. To which is appended, The Grand Impostor discover'd; being Remarks upon the Practical and Philosophical Scheme of the Secret Disease; wherein is made appear by undeniable Demonstration, the Insufficiency of that Author's Royal Specifick (which is
} 


\section{The Anodyne Necklace: A quack remedy and its promotion}

Further defences and attacks masquerading as testimonials appeared in the newpapers on behalf of either "the Grand Specifick" or "The Royal Specifick". 45 But neither of these competitors for this side of the lucrative business survived against the Anodyne Necklace and its 'Practical Scheme', a document which, as the "Five and Twentieth Edition" of 1719 says, had been "Published since March 1713".46 It became something of a flagship for the firm, and Mrs Garway altered her shop sign to the "Practical Scheme"; the pamphlet was still going strong in 1742, 30 years after its introduction. 47

The title 'Practical Scheme' was altered several times over the years to include whatever the promoters wanted to advance on the public, though the pamphlet could always be issued as a simple treatise on venereal conditions. ${ }^{48}$ So sometimes 'Practical Scheme' was expanded into a catch-all title advertising a variety of treatments for a variety of conditions in a series of "treatises" or "discourses", seven or even nine at a time. They were always "given Gratis at the Anodyne NECKLACE without Temple-Bar, at Mrs Garway's, the Sign of This Book at the Royal Exchange-Gate; and at Mr. Cooper's the Corner of Charles Court in the Strand", or at other outlets as time went by. ${ }^{49}$ Sometimes the discourses were said to be "useful", and occasionally they were "Physical". 50 In some form or other, then, the 'Practical Scheme' remained before the public eye, and under that umbrella many venereal remedies were promoted, the firm always having their sights on whatever was currently fashionable.

Being in the venereal trade meant cashing in on anything that might be guaranteed to bring in the customers, and the enterprising firm was as active on the fringes of sexuality as it was in its disease. Some of its publications are known only through the newspaper advertisements, and might well have been pornographic. ${ }^{51}$ The firm was, for instance, very quick to cash in on the question of masturbation, raised acutely by the publication of Onania ${ }^{52}$ in 1708 . Although this was by no means the first book to

sold at Mr. Pratt's at the Angel in Cornhill; and at Mr. Barnet's a Perfumer over-against the Hay-Market) to perform any Radical Cure, \&c. by S.T. M.D. ...”.

45 The Weekly Journal, 4 and 11 Jan. 1717/18.

46 BL 1174 b. 11 (2).

${ }^{47}$ It was advertised in 1742, in A new way of breeding canary birds . . [BL 7286 p. 110, and the John Innes Institute Library, Norwich].

${ }_{48}$ E.g., BL 1174 b. 11 (2), of 1719; BL T420 (14*), of 1730; and BL 7286 p. 110, of 1742.

49 The Daily Post, 12 Oct. 1720.

50 The Original Weekly Journal, 9 Jan. 1720.

51 E.g., 'Curious LETTERS. From a Gentleman at CONSTANTINOPLe, in the Retinue of his Excellency the Earl of Kinnoul, his Britannick Majesty's Embassador at the Ottoman Port, to his Friend in London. - Giving a most curious Account of the Turkish wOMEN in General. Of their Wives and Concubines. Of the Grand Seignior's Seraglio, and his Ladies in it. Of the Two Sorts of Eunuchs that Guard those Ladies, viz. Those Eunuchs who have but HALF cut off, and Those who have all Clean Cut off. How, and Why they are made so. / Of the Market in Constantinople Every Wednesday for Buying and Selling of Women, and of a Custom of Hiring Men to BE with Brides the First Night . . . / This Curious Book will NOT be Given to any Boys, Nor Girls, Nor Any PAULTRY PERSONS, notwithstanding the most Plausible Pretence they may make for their being Sent for it. / But to Creditable Persons it is GIVEN GRATIS ...

52 The title-page grew more elaborate over the years, but the basic title was, 'Onania: Or, the Heinous Sin of Self-Pollution, And All its Frightful Consequences, in both Sexes, Consider'd / With Spiritual and Physical ADVICE to Those who have already Injur'd themselves by this Abominable Practice. / To which are Added, / Divers remarkable Letters from such Offenders, to the Author, lamenting their Impotencies and Diseases thereby. / As Also / Letters from eminent Divines, in Answer to a Case of ConsCIENCE, relating thereto. / As Likewise / A Letter from a LADY, to the Author, [very curious] and another from a 


\section{Francis Doherty}

discuss the topic, ${ }^{53}$ its 15 editions during the century attest to its popularity. This notorious book itself was promoting two quack venereal remedies of its own, "The Strengthening Tincture" and "The Prolifick Powder" from "Mr. CROUCH the Bookseller, who sells this Book". 54 All the more reason why its imitation, the Anodyne Necklace's Eronania, should do the same. This was one of several works which capitalized on the resonant title Onania, ${ }^{55}$ and, as always, the firm produced the most sensational title-page that it could reasonably contrive.

The Weekly Journal on 1 February 1724 published one of the firm's best advertisements:

\section{Publish'd this Day the Particulars of ERONIA}

on the Crimes of those unhappy Brothers ER and ONAN Judah's two Sons, who for defileing their Nuptial Bed, and frustrating the end of marriage, were punished with immediate Death. Gen. 38. Or the hainous Crime of Self-Defilement, with its Nine miserable Consequences of SELF EMASCULATION, Impotency, Sterility, unfitness to Marry, deprivation of Manhood, Seminal Gleets, and the other Three wretched Miseries of it in both Sexes, (whom it generally Initiates in Wickedness) laid open to all Persons ever guilty of this Vice, whether Single, Married, Widdowers, wOMENHATERS, or Molles: And why this infamous Word MOLLES made English is applied to the Doers of this ill Action.

Felix quem faciunt Aliena pericula Cautum

Also, of the Use, Abuse of, frustrating, and defileing the Marriage Bed: With all Doubts thereunto belonging (as also of Rententio Seminis, and it's Consequences in the Body, where the Debitum Conjugale cannot be) solved.

Hoc nihil esse putas? Sidus est, mihi crede, sed Ingens.

Quantum vix animo concipis esse tuo?

Ipsam tibi crede Naturam dicere rerum.

Istud quod ... Pontice Perdis, Homo, est. Martial.

With the Particulars of a scarce Tract cited by a late Author page 25 on this Crime; entituled, Letters of Advice from two Reverend Divines to a young Gentleman about a weighty Case of Conscience, viz. of Defileing himself, to which he was so grievously addicted, that he had well nigh bereft himself of his Manhood.

After Onania many of the venereal remedies took more account of the fears about masturbation's effects, and we see a positive incorporation of the terms "Gleets and Weaknesses" attributable, among other causes, to "Self-Pollution"; 56 or "SEMINAL

Married-Man, concerning the Use and Abuse of the Marriage Bed, with the Author's Answer. And two more from two several young Gentlemen, who would urge the necessity of SELF-POLLUTION; and another Surprizing one, from a young married Lady, who by this detestable Practice became Barren and Diseas'd .....

${ }_{53}$ The most recent commentator on Onania is Peter Wagner, 'The veil of medicine and morality: some pornographic aspects of the Onania', Br. J. eighteenth-cent. Stud., 1983, 6: 179-84.

54 Onania, 6th ed., London, 1722, pp. 98-104.

${ }^{55}$ See Robert H. MacDonald, 'The frightful consequences of onanism: notes on the history of a delusion', J. Hist. Ideas, 1967, 28: 423-31.

${ }^{56}$ E.g., 'The Miscellany: Giving An Account of the Religion, Morality, and Learning of the Present Times. With Occurrences Foreign and Domestick. By Richard Booker, of the Temple, Esq.,' 23 Dec. 1732: “Dr. TILNEY's true Restorer of Nature: Or Famous, Chymical, GREEN-DROPS, So well known, for the real, safe and speedy Cure Of all Sorts of Gleets and Weaknesses, and those other Ailments and Infirmities of the Seminals and Genitals, which hinder Procreation and are Impediments to the Act of it, as well as the Desire 
and GENITAL Imbecilities", which are "Gleets and Weaknesses", "The Bane of Virility, or Manhood, in the one Sex, and Destroyer of Fertility or the Bearing of Children, in the other", again, among other causes, attributable to "Self-Pollution (that cursed School Wickedness, which spoils all our Youth, by nipping their Manhood in the Bud)". 57 Nonetheless, the standard sexological work was the 'Practical Scheme' and its variants. ${ }^{58}$ These were treatises that told you how you could cure yourself on a journey, ${ }^{59}$ those which were intended for patients who only had a "common OUTSIDE Venereal Infection", 60 those which offered a survey of "the various Methods of Cure of the VENEREAL or SECRET DISEASE", various issues of a work on "a BROKEN CONSTITUTION", a 'Pharmacopaeia Venerea: Or, A Complete Venereal Dispensatory' and so on. New nostrums were revealed, like the "Specifick Bolus" of 1721 to 1728 , to be found in the "Treatise (just published) Of the Symptoms and Cure of a Gonorrhea".61

Alongside venereal diseases and associated sexual matters, there was a constant and thriving business in "gout". Right from the beginning, when the critic scathingly mocked those who might pretend that a nostrum that one day was sold as a specific for the pox could next day double as a cure for the gout, advertisements cashed in on people's pain. In 1717 was published 'A New System of the GOUT and RHEUMATISM, drawn from Reason, Anatomical Observations and Experience'; in 1720 it was 'The GOUT truly and fairly stated in a few Words', as the fourth of the 'Discourses' and of the 'Discourses of the Practical Scheme'; in 1723 as 'The GOUT and Weaknes [sic] DIARIES. Also the secret-Patient's DIARY', as the second part of an advertised cure for "Recent or old GLEETS, or other such WEAKNESSES" where the GOUT would be "surprisingly Cured, so as not to return by a Particular Specifick Secret to be taken by Drops in a Glass of Wine", or as an advertisement by itself. ${ }^{62}$ Later the firm attached itself to famous names and rode on their backs, putting the names in bold type alongside an effective logo of a man with a heavily bandaged foot on a stool. So we

towards it, both in Men and Women, whether from a natural Coldness ... or from Strains, excessive Coition, or Self-Pollution, which latter in young People forces Nature before she is ripe, and stints the Growth and Vigour of Youth all which unnatural Evacuations, drain the Vessels, hurt their Tone, run off the Strength of Youth, and by Degrees rob them of their Vigour and Fertility, insomuch, that when those People come to marry, they have puny, weakly, half-got Children, if any, who, if they live, are a Reproach to their Parents, and a Misery to themselves...".

57 The Daily Journal, 20 Oct. 1732, advertisement for the "most Noble Cleansing and Strengthening ELIXIR" of "Dr. R. NELSON".

58 Advertisements were placed early, from 1717 onwards, for the 'Practical Scheme of the Secret Disease and Broken Constitutions' in "French, High-German, Low Dutch. Spanish, Italian, Portuguese, Swedish, Danish and Polish Languages, for the Use of Forreigners".

${ }^{59}$ BL 1405 c. 26 (15): 'Of Persons on a Journey Cureing themselves of the Secret Disease, or a Gleet, whilst they Bait, or Set up at their Inn, without the Knowledge of any one . ., 1733.

60 The Country Journal: Or, the Craftsman, 1 Dec. 1739: "Just Published-A Plain Account / Of that common OUTSIDE Venereal Infection, / Which not One in 20 Escape ...".

61 The "Specifick Bolus" seems very like "the Famous Anti-Venereal Bolus" being sold simultaneously in 1721 by one of the favourite outlets for Anodyne products, "Mr. Gregg's Bookseller, next to Northumberland-House at Charing-Cross in the Strand". The Anodyne Bolus lasted longer, so we presume a takeover; they raised the price of their "bolus" from 1 shilling in 1721 to 25 . $6 d$. in 1728 .

62 E.g., The Daily Post, 9 Aug. 1721: "The Gout surprizingly cured by a particular Specifick Secret to be taken in a Glass of Wine. It takes off the most torturing fit, and gives immediate Ease, and so carries off the Gouty Matter, as effectually to secure the Stomach, Head, and other noble Parts, from being attack'd ...". 
have both 'Dr. SYDENHAM's Experimental Observations on the GOUT', ${ }^{63}$ and 'The HOSPITAL SURGEON OF THE GOUT, Rheumatism, Cholick, Dropsy, Stone, GRAVEL, and Venereal Complaints', ${ }^{64}$ the latter cashing in on the name of Belloste. ${ }^{65}$

For "gout" they tried a nostrum which, because it was based on the same "principles" as the Anodyne Necklace, and claimed to cure by releasing influences from a physical source that was carried on the body to the affected parts by "sympathy", ought to have had the same measure of success. But this "Gout Stone" of 1722 and 1723 had a short run. ${ }^{66}$ The problem was not merely that of persuading a usually gullible public with no effective cures for rheumatism, arthritis, etc., and thus willing to try anything once. There was a rival. Another firm was pushing its "Sympathetic Composition", brought over, it was claimed, from America, and carrying the very high price of five guineas. A newpaper war was waged in the advertising columns, the language colourful and libellous. The "American" marketing firm gave a comic account of "Anodyne", "going in Disguise, into Coffeehouses, and observing the Conversation of the judicious bend upon declaiming against him and his Chymerical Stupendous" which makes him alter his price to five guineas to keep up. They also dismissed "Anodyne"'s attempts to justify himself and to vilify them, in his turn. This was seen as "an exertion with all his dismal Rhetorick to blacken that which is out of his Power to conceive", as

he flies from one Falsity to another, till at last, like one just drowned, he is willing to catch at every Rush, and now, past Hope, and gasping for Breath, proposes Things which he leaves a Woman to perform not daring to comply in Person with his own Offers. ${ }^{67}$

It was "Anodyne" who had attacked first, in January $1723,{ }^{68}$ desiring Dr Mead, "or any Gentleman" to compare the two compositions which were waiting to be examined, "Open, as they are", "up One Pair of Stairs at the Anodyne Necklace without TempleBar", and to see that the opposition's rubbish is only "about two Inches of Common little Roll BRIMSTONE, which may be had for a Half-penny at most Grocers Stores ...". But the same examination would, of course, reveal that "the GOUT-STONE is a real Medicinal Stone, and not so much as even like it, and consequently can be no manner of Counterfeit of it." But, counterfeit or no, it had a short life, despite a new logo with the motto, "I TOUCH \& HEAL", and an advertisement that was a testimonial from "the Mistress of the Shop next to the Goat in Dartmouth-street, Westminster" that she had been cured, though before using the medicinal stone "she could not lift her Hand to her

\footnotetext{
${ }^{63}$ E.g., Mist's Weekly Journal, 13 Jan. 1728.

${ }^{64}$ E.g., The Daily Post, 30 Jan. 1738.

65 Augustin Belloste's Le chirurgien d'hôpital of 1700 was translated in 1706 as The hospital surgeon and was popular enough to be reprinted the following year.

${ }^{66}$ E.g., The Weekly Journal, 17 Nov. 1722, announces that a treatise is to be prepared (while it details the case of a lady who was remarkably cured by GOUT STONE); on 30 March 1733, the same newspaper carried an advertisement which says that the treatise is given away "at the Anodyne Necklace".

67 The London Journal, The Second Supplement to the London Journal, 4 Feb. 1722/3.

68 The Weekly Journal, 19 Jan. 1723.
} 
Head, nor use a Leg". ${ }^{69}$ It was still being promoted in 1725 in "The Secret Patients DIARY. Also the GOUT and Weaknesses DIARIES . ., ${ }^{70}$ but then we hear no more of it.

\section{THE "USEFUL" PAMPHLETS}

Perhaps the most enterprising of the ventures associated with the Anodyne Necklace was a series of pamphlets that were not produced to promote a nostrum directly, or directed ostensibly to medical conditions, with the nostrums bringing up the rear, but that were modelled on the shorthand pamphlet. These "useful" free pamphlets were aimed at a middle-brow, lower middle-class readership, the new class in early eighteenth-century England. This meant that the producers had to have journalistic flair to catch the mood of the times, the feelings and fears of the target audience, and an ability to capitalize on current events.

Great success, for example, attended a series of pamphlets on the plague, with the scare that the Great Plague of 1665 might be repeated in Britain, following an outbreak at Marseilles in 1720. As we know from the number of publications, such as books of remedies, methods of prevention, histories of the plague, pamphlets and advertisements, and from Defoe's Journal of the plague year, as well as the draconian measures for quarantine rushed through Parliament, there was genuine alarm throughout the country. Anodyne Necklace cashed in early, and kept up its momentum for a whole year. Its first pamphlet was announced on 4 November 1720, and the temperature of the title-page, published as the announcement in the press, was as high as any scaremonger could wish.

To Morrow will be publish'd, purely for the Publick Good,

The dreadful PLAGUE at Marseilles consider'd and compared with that terrible Plague in London, in the Year 1665, in which dy'd above 100,000 Persons, between 8 and 9000 being commonly swept away every Week; the common Sight in London Streets being nothing but Carts loaded with dead Bodies, and the Carmen crying out, BRING OUT YOUR DEAD, BRING OUT YOUR DEAD. Together with the Method of Cure used to those who recover'd in London; and Rules for its Prevention and Cure. Publish'd purely for the Preservation and benefit of all Persons who may at any Time be where this terrible Marseillian Infection may reach: And is given Gratis only Up One Pair of Stairs, the Sign of the celebrated Anodyne NECKLACE, recommended by Dr. Chamberlen, for Children's Teeth, next to the Rose Tavern without Temple-Bar. And no where else. ${ }^{71}$

It was always possible to raise a temperature in the advertising world, and a year later the rhetoric was very exalted indeed:

Concerning the dreadful PLAGUE which now so alarms all Europe Whereas this terrible Calamity not only rages still in France with such Violence, that whole Families lie Dead at once in a House (the Living not being sufficient to bury them) but is also very much feared will be brought over hither; Notice is hereby given to all families, that new Instructions are now publish'd, by which Persons may provide in

${ }^{69}$ The Weekly Journal or Saturday's Post, 30 March to 4 May 1723.

70 BL 1174 b. 11 (3).

${ }^{71}$ The London Journal; The Daily Post; The Post-Man; The Weekly Journal: Or, British Gazeteer; The Weekly Journal or Saturday's Post; The Flying-Post; Applebee's Original Weekly Journal; The Daily Courant. 
Time against this destroying Angel of Mankind, fully containing the whole SCENE of SER VICE, during whatever attack this terrible Calamity may make upon any Family ... ${ }^{72}$

The firm must have been delighted to announce at least twice, once in November 1720 , and again in February 1721, that it had to reprint the pamphlets, the demand having been so great for "those few Thousands which were at first printed off". Despite this seeming success the pamphlets were well-advertised in many newpapers. ${ }^{73}$

Other subjects of equal public interest resulted in pamphlets, free to anyone who cared to call for one, though, occasionally, with the announcement (when the topic was "dangerous") that no boy or girl sent for one would be allowed to have it. Often the pamphlets would have been recognized by a well-educated audience as deriving from named and often well-known sources. A Swift, for example would have seen quite clearly that Bishop Francis Godwin's work, The man in the moon (1638) was the source for the firm's pamphlets on the migration of birds. Godwin's work had been an early exercise in projecting the theory of gravitation in a fantasy. He invented a man, one Domingo Gonzales, who, marooned on the "blessed Isle of S. Hellens, the only paradise", learns to use the local large birds, "gansas", as a means of transporting himself from part to part in a kite-like structure. After a series of adventures, he is taken by them, along with other migrating birds, up into the moon. He stays there for 18 months, then is brought back to earth in a reverse migration. ${ }^{74}$ The Anodyne Necklace advertisers, shamelessly pillaging this science fiction, tried to persuade readers that indeed a man had been up to the moon, and that their pamphlet was a record of matters of fact, and so they produced their "Enquiry" of their "Solution", "of the Question/Where the SWALlow, the NIGHTINGALE, the/WOODCOCK, FIELDFARE, Cuckow, \& other / Birds of Passage Go, when Absent from us". 75

Again, when eclipses were looming, then there still was some residual fear in the population about signs and portents, remnants of older ways of thinking about the heavens. The firm obliged by offering its free pamphlets. A "Great and Total" eclipse of the sun, predicted for Monday 11 May 1724, was prepared for by an appropriate pamphlet that would

lessen the Consternation that People, ignorant of the Cause of Eclipses may be put into... when it will be so surprisingly Dark, that the Stars will be seen, an exact Curious Draught shewing at one View, the whole gradual Passage of the Moon over the Sun's Body, as it will appear in England, Scotland, Ireland, France, Holland, and the Low Countries, and other Parts of Europe; with a necessary Caution Looking at it ... ${ }^{76}$

${ }_{72}^{72}$ Long and terrifying advertisements appeared, e.g., in the newspapers from November 1720 to May 1721.

${ }_{74}$ E.g., The Weekly Journal or Saturday's Post, 28 Jan. 1721.

${ }^{74}$ See Grant McColley, 'The Man in the Moone and Nuncius Inanimatus for the first time edited, with introduction and notes, from unique copies of the first editions of London, 1629 and London 1638', Smith College Stud. mod. Languages, October 1939, 19(1); and idem, 'The third edition of Francis Godwin's The Man in the Moone', The Library (Transactions of the Bibliographical Society), 1937, 17: 472-5.

${ }^{75}$ The Weekly Journal, 15 May 1725 advertised, as just published, 'A New Edition of, An Account of the PLACE Where the Nightingale, the Swallow . . . The Wellcome Institute Library's undated 'Enquiry' must be earlier.

${ }^{76}$ The London Journal, 2 and 9 May 1724. 
Equally, the "Great Formidable Eclipse of the Moon" was predicted for 10 October 1725, and the splendid advertisement for its pamphlet showed a large moon as a scowling face. Readers were warned that a "brighter, resplendent Full Moon will be so totally disfigured as to appear very formidable ...". But they need have no real concern, as the true natural causes would be shown them in the pamphlet:

And as this Apparition will not be caused by the Immersion of the Moon's Body in the Shadow of the Earth, as commonly is imagin'd, therefore (to lessen the Consternation and Surprise this frightful Appearance in the Heavens may cause)

A TRUER Account of it, with a curious Draught of the Interposition of the Earth and its Atmosphere between the Bodies of the Sun and Moon, is publish'd. ${ }^{77}$

A Wild Boy was brought to England from Hanover in 1725, who had been found living alone in the woods at about the age of 12 . Speculation raged as to how he had survived (as was presumed, falsely, from infancy) all that time in the woods. "Peter of Hanover" became something of a celebrity, was placed under royal protection, and spent the next 68 years in captivity. ${ }^{78}$ The advertisers issued an eight-page pamphlet, embellished with a woodcut-as was their practice-showing Peter in civilized clothing, but with bushy, unkempt hair, a crouching wild beast on his left, and a boy up a tree on his right. The pamphlet speculated, as everyone else was doing, about his survival in the woods, and it gave readers a glimpse of Peter's messy behaviour at court. $^{79}$

But Hanover meant more to Englishmen whose King was Hanoverian than wild boys who happened to be found in woods there. At times there were murmured complaints that the monarchy was over-involved with the affairs of Hanover, to the detriment of England. So when the King, George I, died at his home-town of Osnabrück on a journey to Hanover on 11 June 1727, there was a surge of hope that England might yet escape from the Treaty of Hanover (of September 1725, between England, France, and Prussia), which threatened to lead Britain into a European disaster. Such sentiments might be thought of as Tory, or even Jacobite, but the advertisers cashed in on them too. They produced their pamphlet, 'The Englishman's Two Wishes. One That Hanover was Farther. The other, That__ \&c. Dicere VERUM, Quis Vetat? Hor. Tell the Truth, and shame the Devil' ${ }^{80}$

Again, when in 1733 there was a recoinage and hammer-struck gold coins that had been issued before 1663 were proclaimed, on 21 and 26 February, to be no longer

77 The Weekly Journal, 4 Sept. and 2 Oct. 1725.

${ }^{78}$ See Lucien Malson, Wolf children, London, NLB, 1972 (translation of Les enfants sauvages, Paris, Union Geńerale d'Editions, 1964), ch. 2, 'Legendary and historical accounts', p. 41. In a letter from Swift to Tickell, 16 April 1726: "This night I saw the wild boy, whose arrival here hath been the subject of half our talk this fortnight. He is in the keeping of Dr. Arbuthnot." (The correspondence of Jonathan Swift D.D., ed. F. Elrington Ball, London, 1912, vol. 3, p. 304). Either Arbuthnot or Swift wrote It cannot rain but it pours: or, London strew'd with rarities . . of 1726 , which uses Peter in a satirical way.

79 "The King was pleased to have him with a Napkin pin'd before him at his Table, to see how he would eat, and behave himself, he had no Notion of Behaviour, or Manners, but greedily took with his Hands out of the Dishes, what he liked best, such as Asparagus, or other Garden-things, and after a little time, he was ordered to be taken away, by Reason of his daubing undecent Behaviour."

${ }^{80}$ Advertised in Mist's Weekly Journal, 3 Feb.-30 March 1728, and in The Country Journal, 10 Feb.-6 April 1728. 


\section{Francis Doherty}

legal tender (though they had for years been refused by banks and revenue officials), the advertisers were ready to strike a bargain. They proposed to accept the non-legal coins as payment for the Anodyne necklaces "or any of the other Things there are mentioned in the Books that are There Given away Gratis", as they advertised in the press. ${ }^{81}$ As ever, they claimed a philanthropic motive, because "whatever is thus received, will be exchanged at the Mint all together afterwards, and the Author of the Anodyne Necklace will take all the Loss to himself."

Exactly what was being promoted in 1736 when there was a new 'Act of Parliament against GENEVA, and Other SPIRITOUS LIQUORS' we have no knowledge, but it was "A HOLE TO Creep OUT $\boldsymbol{A} t$ ". It was a "new Dramm, far better than GIN, and a New PUNCH far WHOLESOMER than either Brandy, Rum, or Arrack Punch."82

The business of drink entered the firm's pamphlets several times. In 1730 they followed a healthy drinking line by a pamphlet on 'WARM DRINK'. In 1724 there had been a pirating of an old publication of 1641 , which had proposed that warm beer was better for you than cold beer: '[W]ARME BEERE. OR TREATISE WHEREIN [d]eclared by many reasons, that Beer so qualified is farre more wholesome then that which is drunke cold. / With a confutation of such objections that are made against it; published for the preservation of health . . ${ }^{83}$ With only the occasional alteration of a word here and there, this was stolen and reprinted, without acknowledgement, in $1724 .^{84}$ The idea that cold drink is bad for you struck the advertisers as being good for their gout cures, so they ran their own

WARM DRINK A TREATISE SHEWING That Drink (whether Beer, Ale, or any other Liquor) so Qualified, much better Quenches THIRST, and is far more Wholesome, than if Drank Cold.

And its Particular Advantages in the Gout, A Consumption, and all Nervous Distempers. With a New SYSTEM OF THE GOUT \& Rheumatism.

Drawn from Reason, Observations, and Experience. Shewing the right Method of treating the GOUT. ${ }^{85}$

Everything taken by mouth seems to have been part of the business, and when there was an attack on the taking of tobacco in 1720 , the advertisers, already committed to the marketing of their excellent "Cephalick and Opthalmick Tobacco", 86 issued two versions of a comprehensive treatise. This was

${ }^{81}$ Read's Weekly Journal, or, British Gazeteer, 10 March-21 July 1733.

82 The Country Journal, 7 Aug.-13 Nov. 1736.

${ }^{83}$ BL 1170 a. 13.

${ }^{84}$ BL 1171 d. 16 (3).

${ }^{85}$ BL 7420 (14).

${ }^{86}$ An "Ophthalmic-Tobacco, which Smokes very mild and grateful to the Smell, approv'd on by several emminent Physicians to be a sovereign Thing for Eyes" was advertised in Applebee's Original Weekly Journal on 28 January 1721 by "Charles Stokes, Stationer". In July the same newspaper carried the first Anodyne version. This was for its "Cephalick and Opthalmick robacco for the Head, Eyes, Stomach, and Lungs". The first version had claimed that anyone who smoked the tobacco "will (by the Blessing of God) never use Spectacles". The August insertion of the Anodyne advertisement went further: "It so Strengthens and Restores Ancient Sight, and preserves Young Eyes, that by the Use of it, Persons may (thro' the Blessing of Almighty God) never come to wear. Spectacles, and if they already used them, may come to leave them off, it so strengthens and clears the Sight." 
The Anodyne Necklace: A quack remedy and its promotion

\section{Of the Use of Tobacco, Tea, Coffee, Chocolate, and Drams. Under the following Heads.}
I. Of SMOAKING Tobacco, as commonly Practised. And of what Service Tobacco is in the PLAGUE.
II. Of CHEWING Tobacco.
III. Of Taking Tobacco in SNUFF.
IV. Of the Use of Tea, (Green, and Bohea).
V. Of Drinking Coffee. And Throwing its Grounds.
VI. Of Chocolate, and Vanillas.
VII. Of Brandy, Rum, GENEVA, and other Drams.

With Rules for Smoaking, Taking of Snuff, Drinking Tea, Coffee, \&c. so as to prevent any ill Effects on the Nerves.

This had a woodcut of CEPHALICK \& OPTHALMICK TOBACCO, and, as might have been expected, it poured scorn on any of the ways of taking tobacco (viz., chewing it) that this advertisement itself was not promoting. "Dr. Car" is quoted as saying that chewing was "not advisable", "by reason on a very Malignant Salt that Tobacco abounds with"; "Ramazzini", it is said, in his Treatise on Tobacco held that "he knew a great many brought to Consumptions by Chewing Tobacco"-and the firm felt justified in condemning the practice. But anything that the firm recommended, its medicinal snuff, its cephalick tobacco, was of course medicinally useful.

Again, because only the newspaper advertisement survives, we cannot really know what lay behind a 1736 pamphlet. This was 'A Cure for Too Much Manners, Compliments, NO I THANK YOU, What You Please, Unmannerly Curiosity and Impertinence' ${ }^{87}$ But others, as we have seen, can be related to specific historical circumstances, while others were shameless plagiarisms. Of these literary thefts, two are especially interesting, because they are part of the new higher journalism of the Augustan age. There were two papers taken from the Tatler of Addison and Steele.

The first of these, initially published as Number 249 for 11 November 1710, was plagiarized in 1728 , but its life which certainly stretched into the $1740 \mathrm{~s}{ }^{88}$ The Anodyne version was 'The HISTORY of the travels and Adventures of a Shilling, from Queen Elizabeth's Reign to King George II time; with it's several Coins and Changes, finely engraved . . .89 Steele's original essay had been a fantasy-history of a silver shilling from its origin in Peru, its journey to England "under the convoy of Sir Francis Drake", down to an incident in 1703, when it was "given away in charity to a blind man ... by mistake". The account is gentle, avoiding the possibilities inherent in the tale for satire or anger, and is mainly moralistic in tendency. ${ }^{90}$ Steele had

87 The Country Journal: Or, The Craftsman, 17 April to 24 July 1736.

${ }^{88}$ E.g., advertised in March and April 1728 in The Country Journal, and a notice for it was part of $A$ new way of breeding canary birds, 1741.

89 Wellcome 69143.

${ }^{90}$ Such pseudo-histories had quite a vogue later, e.g., Thomas Bridges, The adventures of a bank-note, 4 vols., London, 1770-1; Helenus Scott, The adventures of a rupee, wherein are interspersed various anecdotes Asiatic and European, London, 1782; “R.J.", The adventures of a silver penny . ., London, 1782(?); "R.J.”, The adventures of a silver penny. Including many secret anecdotes of little misses and masters both good and naughty. Embellished with cuts, London, 1787(?); W. Truslove, The adventures of a silver three-pence ..., Burslem, 1802(?); The adventures of a halfpenny, commonly called a Birmingham halfpenny, Or counterfeit; as related by itself, Banbury, 1835(?). 
written for a comfortable, middle-class readership, and the adventures are in keeping with that audience's values. They could be expected to appreciate the gentle jokes; and Steele's compliment to a contemporary poet would, no doubt, have been taken as graceful and well-turned in the description of two unique adventures, neither of which

ever happened above once in my life. The first was, my being in a poet's pocket, who was so taken with the brightness and novelty of my appearance, that it gave occasion to the finest burlesque poem in the British language, entitled, from me, The Splendid Shilling. The second adventure, which I must not omit, happened to me in the year 1703, when I was given away in charity to a blind man; but indeed this was a mistake, the person who gave me having thrown me heedlessly into the hat among a penny-worth of farthings. ${ }^{91}$

Anodyne's shilling follows Steele for most of its length, but addresses itself at the end to its own particular audience, people who would know what a shilling could be expected to do in their world's systems: "Innumerable are the times I have been sent for a Pack of Cards; given after Dinner to a Waiting Servant. During Summer Seasons I often treated People with Cakes \& Ale in the Fields, Or Regaled some Journeyman Taylors with Eighty and Forty Morsels at a Farthing Pye House." But the greatest adventure, the point of the pamphlet, was when the shilling came into the possession of "Mr HULL", a clockmaker of Bedfordshire. He came to London and "bought with ME \& Four more of my own Rank an ANODYNE NECKLACE ...". And the testimonial from Mr Hull is printed, mostly in italics, and dated 21 July 1727. Then, after two further short paragraphs of adventures, our newly re-minted shilling is ready for more action: "And I am again as ready now to List Soldiers (if need should be) Or carry any Person a Mile in a Hackney Coach, Or Fetch a Warrant, a Pint of Wine or a Pack of Cards, Or for any other Twelve Penny Errand, as ever." So, adorning a title-page with engravings of shillings, and making much of the title, certainly elevated what had been a routine tea-table Tatler paper into an elaborate advertising puff for the Anodyne Necklace.

Having had one success in raiding an old work, the firm struck again later in the same year, 1728. They published on 31 August, 'A Dissertation on Noses' 92 The Tatler for 7 December 1710 (no. 260) had been a playful paper on noses. It had quoted from Butler's Hudibras the passage, itself an old chestnut, an elaboration of a tale told of "Taliacotius ... an Italian Chirgeon, that found a way to repair lost and decay'd Noses":

91 The British essayists; with prefaces biographical, historical, and critical, by the Rev. Lionel Thomas Berguer, 45 vol., London, 1823, vol. 5, p. 170.

92 Mist's Weekly Journal 31 Aug.-21 Sept. 1728; Fog's Weekly Journal 28 Sept.-19 Oct. 1728: This day is Published / A Dissertation upon NOSES, viz, On the / Long High Roman NOSE, (as was the Fashion in K. William's Days.) On / the Large Bottle NOSE. ON the Snub, / the Flat NOSE. On the little Contemp- / tuous Short Cocking NOSE. On the thin / Pinch'd NOSE. On the Red nOSE. / And on those who have LOST THEIR NOSE_-For / Non cuipiamque datum est habere NA- / sum. Mart. / With all these several Sorts of Noses finely engraved... 
So learned Taliacotius from

The brawny part of Porter's Bum,

Cut supplemental Noses, which

Would last as long as Parent breech:

But when the Date of Nock was out,

Off dropt the Sympathetick Snout. ${ }^{93}$

A chapter in the biography of Gaspare Tagliacozzi tells the story of his rhinoplasty, and quotes some of the many embroiderings on the truth, some of which gave rise to Butler's verse. ${ }^{94}$ Steele continued a line of stories that had been current for 150 years, only to have his essay re-adapted as an elaborate money-catching puff for a quack medicine.

Central to the firm's success was the old doctrine of "sympathy", whereby influences could travel over space and have a profound effect at a considerable distance. The nose that "Taliacotius" grafted from someone else's flesh (the arm-Butler wrote, "Bum") dies when the original "owner" dies. This was only further proof, if indeed such were needed, that the Anodyne Necklace was bound to work, incorporating as it did the principle that underpins the story of "Taliacotius". Science sells nostrums; and what had been a diversion for the tea-table can become a hard sell in the market-place.

Any means to catch the public eye, the clever use of the advertisement columns of the newspapers, eye-catching logos, and plays on popular fears, superstitions, and beliefs, were all used. Just at this time advertisers were becoming masters of the free "treatise". Many of them are lost, but enough survive to show that type was constantly being reset for the different "editions", that printing, in some cases thousands at a time, was continuous, and that the printer was a successful businessman in his own right.

The central plank of both the business and the prosperity, the Anodyne Necklace, was kept before the public's eye for very many years, and its name passed into common parlance. ${ }^{95}$ For well over a hundred years, advertisements proclaimed the appearance of treatises on the necklace, which were published, it was claimed, in most of the European languages. In the 1730s, aside from the "Anodyne Necklace", the main outlet for the firm's products and treatises came to be "at Mr. Bradshaw's Stoughtons and Daffy's Elixir Warehouse, at the Golden Key, under the Back Piazza of the Royal Exchange". Robert Bradshaw, who had been associated from the early days, by then seems to have been a powerful force in the enterprise, one of the men who did well from the Anodyne Necklace for many years. However, by the turn of the century control had passed into the hands of one man, Basil Burchell, who marketed both the "Purging Sugar Plums" and the Anodyne Necklace. He operated from the

\footnotetext{
${ }^{93}$ Hudibras II, canto 1, 11. 279-84, first published 1663.

${ }^{94}$ Martha Teach Gnudi and Jerome Pierce Webster, The life and times of Gaspara Tagliacozzi, surgeon of Bologna, 1545-1599, New York, Reichner, [1950], ch. 15.

${ }^{95}$ E.g., in Goldsmith's The Vicar of Wakefield (1766), the son is talking to his father: "My first scheme, you know, Sir, was to be usher at an academy, and I asked his advice on the affair. Our cousin received the proposal with a true Sardonic grin. Aye, cried he, this is indeed a very pretty career, that has been chalked out for you. I have been an usher at a boarding school myself; and may I die by an anodyne necklace, but I had rather be an under turnkey in Newgate...". Collected works of Oliver Goldsmith, ed. Arthur Friedman, Oxford University Press, 1966, vol. 4, p. 107.
} 


\section{Francis Doherty}

"Sign of the ANODYNE NECKLACE, No 79 Long Acre, Two Doors from Great Queen Street, London". 96 As so often in the history of any long-lived quack medicine, he was also fighting off "deceits practised by a set of artful and unprincipled men", "ignorant quacks", who were forging and marketing their own versions of the famous remedies.

Some of these Imposters have not only copied the various Books and Bills of Directions, but have been so transcendantly flagitious, as boldly to assert to those who have gone to their Shops by mistake, that the person who prepared their vile compositions, is the same who prepares them for Mr. BURCHELL; . . ${ }^{97}$

PRINT AND PROMOTION

But by the time that the business had passed to Burchell the alteration was noticeable. Gone are the promotional pamphlets and elaborate use of newsprint to work on current fears or preoccupations. We are left with a successful, long-lived, and by then seemingly respectable quack remedy.

What we have witnessed are some of the ways that the ingenious and enterprising eighteenth-century businessman discovered and exploited to promote his products. This has become an established part of the capitalistic world, and watching the development and diversification (as we would call it) of quack remedy advertising copy, from company logo to the free booklet, is instructive. We see examples of marketing methods and manipulation appropriate to a culture of nearly 300 years ago, and yet they can seem all too familiar. We witness the systematic exploitation of the rapidly-exploding newspaper medium, and continual changes and innovations being played against the constancy of the original product, known for generations and therefore unquestionably to be trusted. We may think of products of the day before yesterday, like "Jenning's Fever Cure" and "Syrup of Figs", as reincarnations perhaps.

But we see, above all, how an advertiser plays on the reader's fears, anxieties, prejudices and concerns, and we can follow this both in progressive changes in advertising campaigns, and in the assumptions, voiced and unspoken, in the advertisements themselves. They address, above all, a male readership-as witnessed, say, by the sexological materials that figure so prominently in the Anodyne Necklace's output. But a father's concern for his family was equally the base upon which much could be built, given the concern of all parents about high infant mortality.

But the single most significant feature of the whole story is the speed and agility with which the quack advertiser both monitored the mood of the moment and responded to it, like any good journalist. Whatever could be capitalized on, whether a plague scare, a curiosity about the moon's eclipse or the migration of birds, was to be used. And for this there had to be a ready copywriter and an organization able to move quickly into print, both with newspaper advertisements and independent

\footnotetext{
96 Wellcome 34221.

97 Wellcome 64640.
} 
pamphlets. This was a golden age of print, when print was not only power, it had its own inherent authority. The pursuit of a complex network of advertising, and advertising methods, during this early period raises interesting questions about training the public to read advertising material, and the ways in which the material developed its persuasive power when concerned with deep anxieties about illness and death.

But an effective organization has to have a system, and the success of the venture can be seen by the fact that a single printer, Henry Parker, for so long published all the material, much of which inevitably, being ephemeral, has been lost to us. Looking at the bald entry for him in the standard handbook of printers of the period might well lead one to believe him unimportant ${ }^{98}$ But his real success and standing can be readily seen when his dynasty is traced in the Stationer's Company Register $1701-1800 .{ }^{99}$ Here he is shown as having 12 apprentices from 1719 to 1727 , two of whom were his sons George and Thomas, who in turn became heads of successful printing firms with sons carrying on the business until the end of the century. And this success seems mainly due to the work associated with Anodyne Necklace.

To the quick-thinking and calculating exploiter of man's anxieties about his health go rich rewards, and Anodyne Necklace is an interesting early example of this.

\footnotetext{
98 Henry Robert Plomer and others, A dictionary of the printers and booksellers who were at work in England, Scotland and Ireland from 1668 to 1725, ed. A. Esdaile, Oxford, Bibliographical Society, 1922.

${ }^{99}$ Ed. D. F. McKenzie, Oxford, Oxford Bibliographical Society, n.s., vol. 19, pp. $260-2$.
} 